\title{
Microbiological hazard in buildings based on the example of dwelling houses and public utility buildings in Warsaw
}

\author{
ALEKSANDRA WÓJCIK \\ Faculty of Wood Technology, Department of Wood Science and Wood Preservation, Warsaw University \\ of Life Sciences - SGGW \\ E-mail: aleksa.wo@gmail.com
}

\begin{abstract}
This paper contains preliminary results of mycological research in residential and public buildings in Warsaw and its surroundings. The study focuses on the qualitative survey of fungi in buildings of various categories. It includes research objects divided into six categories depending on the age of the buildings and their use: new buildings and the objects of about twenty years and older, as well as twenty-year single-family houses. Two houses that are in the registry of monuments (National Heritage Institute) were also in the scope of the analysis. There have also been attempts to classify the identified species of fungi into groups of BSL (Biological Safety Level), in order to identify their potential allergenic impact on buildings users. In more than half of the studied objects the most frequently isolated species was Alternaria alternata (55\% of cases) and fungi of the genera Aspergillus and Penicillium. Aspergillus niger was identified in 33\% of the objects, exclusively in the neglected buildings, including those abandoned for at least one year.
\end{abstract}

KEY WORDS: moulds, mycology, building, allergy

\section{Introduction}

Mould fungi commonly exist in becoming affected (Wiejak 2011). There dwelling houses, not only in old, neglected tenement houses or ones that have not been renovated for a significant amount of time. This problem often and increasingly concerns new buildings, including the undressed ones. Currently, apart from more than 100-year-old historic buildings, new constructions, including ones that have not been commissioned, are also are numerous causes of mould fungi occurrence, such as the optimal humidity of air or walls due to construction defects. Other factors include the increased temperature and, along the $\mathrm{pH}$ value, poor air circulation and the access to light required for sporulation (Piotrowska 2012). The fungi spread to dwelling houses from the outside, their spores are suspended in the air and 
become a constant element of the bioaerosol of the rooms, alongside the bacteria and viruses (Zyska 2010). Unfortunately, the occurrence of mould fungi in dwelling houses and public utility buildings is a health hazard for the residents and users. A common cause of this problem is faulty ventilation system resulting from both construction defects and the wrong use of the building. Additionally, wrong horizontal and

\section{Material and methods}

Thirty six buildings were divided into six categories based on the purpose of the building, age and type (one-family, multifamily or public utility) and surveyed between 2008 and 2014. Apart from buildings in Warsaw, there were also three in Konstancin-Jeziorna, and one in Jabłonna, Łomianki and Brwinów. Sixteen buildings were over 20-year-old multifamily houses. There were construction defects in all the surveyed buildings, such as damp plasters. In six of the buildings there was faulty vertical or horizontal insulation, in other six buildings walls were prone to frost. Five buildings had insufficient ventilation. In two there was flooding caused by a failure of the water supply network or another defect. Collected microbiological material in the form of microbiological contact plates (three samples for each building and scraping) was incubated. Mould samples were taken from wall barriers using Sabouraud dextrose 2\%

\section{Results}

Sixteen species of fungi were isolated and identified in analyzed buildings (Table 1). In some buildings, several species of fungi occurred and almost all the species identified were present in public utility buildings. The collected data for residential buildings relate to the vertical insulation or freezing of the wall barriers create favourable conditions for mould fungi development. Then, the most often occurring species are primary and secondary colonizers which need humidity 0,75 to 0,9 aw (water activity) (Twarużek 2006).

The aim of the present study was to evaluate and to compare microbiological hazard in residential and public buildings in the Warsaw area.

agar imprint plates or inoculated directly on agar plates (different media supplemented with chloramphenicol in order to eliminate bacterial growth) with the use of a laboratory needle. The fungi were incubated in $27^{\circ} \mathrm{C}$ for approx. 2 weeks. Microscopic (shape, size of conidiophores, conidia and ascospores, diameter of hyphae) and macroscopic features (colour, shape and consistency of colony) were considered during identification. The morphological characters (ascospores, conidia, etc.) were observed and measured (at least 30 elements) under an Olympus D40 microscope with transmitted light. Photographs were taken with an Olympus DP25 camera and CellSense software. Several identification keys were used and fungal names are given according to them (Thom \& Raper 1945, Raper et al. 1949, Navi et al. 1999, Piontek 1999, Watanabe 2002).

period of autumn (from October to December), while the public buildings were analysed in summer and autumn (from July to September). Cross marker $(+)$ indicates the identification of a single species in a given category of buildings, in at least one room. 
Table 1. Fungal species, their origin and classification to the BLS group.

\begin{tabular}{|c|c|c|c|c|c|c|c|}
\hline \multirow[b]{2}{*}{ Species } & \multicolumn{3}{|c|}{ Apartments in } & \multicolumn{2}{|c|}{ One-family houses } & \multirow{2}{*}{$\begin{array}{c}\text { Public } \\
\text { utility } \\
\text { buildings }\end{array}$} & \multirow[b]{2}{*}{$\begin{array}{l}\text { BLS } \\
\text { group }\end{array}$} \\
\hline & $\begin{array}{c}\text { new } \\
\text { buildings }\end{array}$ & $\begin{array}{c}\text { over } 20 \\
\text { years old } \\
\text { buildings }\end{array}$ & $\begin{array}{l}\text { tenement } \\
\text { houses } \\
\text { over } 50 \\
\text { years old }\end{array}$ & $\begin{array}{c}\text { over } 20 \\
\text { years old }\end{array}$ & $\begin{array}{c}\text { over } 50 \\
\text { years old }\end{array}$ & & \\
\hline $\begin{array}{l}\text { Acremonium } \\
\text { charticola } \\
\text { (Lindau) W. } \\
\text { Gams }\end{array}$ & & & & & & + & 1 \\
\hline $\begin{array}{l}\text { Acremonium } \\
\text { strictum } \mathrm{W} . \\
\text { Gams }\end{array}$ & + & & & & & + & 1 \\
\hline $\begin{array}{l}\text { Alternaria } \\
\text { alternata (Fr.) } \\
\text { Keissl. }\end{array}$ & +++ & ++++ & ++++ & ++ & +++ & +++ & 1 \\
\hline $\begin{array}{l}\text { Aspergillus } \\
\text { fumigatus } \\
\text { Fresen. }\end{array}$ & & & & & & + & 3 \\
\hline $\begin{array}{l}\text { Aspergillus } \\
\text { niger Tiegh. }\end{array}$ & ++ & ++ & +++ & + & +++ & + & 1 \\
\hline $\begin{array}{l}\text { Aspergillus } \\
\text { ustus } \\
\text { (Bainier) } \\
\text { Thom \& } \\
\text { Church }\end{array}$ & & + & & & & & 2 \\
\hline $\begin{array}{l}\text { Aspergillus } \\
\text { versicolor } \\
\text { (Vuill.) Tirab. }\end{array}$ & & & & & & + & 2 \\
\hline $\begin{array}{l}\text { Botryotrichu } \\
\text { m piluliferum } \\
\text { Sacc. \& } \\
\text { Marchal }\end{array}$ & & & & & & + & 1 \\
\hline $\begin{array}{l}\text { Cladosporium } \\
\text { herbarum s.l. } \\
\text { (Pers.) Link }\end{array}$ & & & & & & ++ & 1 \\
\hline $\begin{array}{l}\text { Fusarium } \\
\text { oxysporum } \\
\text { s.l. (Schltdl.) } \\
\text { emend. } \\
\text { Snyder \& } \\
\text { Hansen }\end{array}$ & & & & & & + & 1 \\
\hline $\begin{array}{l}\text { Fusarium } \\
\text { sambucinum } \\
\text { Fuckel }\end{array}$ & & & & & & & \\
\hline
\end{tabular}




\begin{tabular}{|c|c|c|c|c|c|c|c|}
\hline \multirow[b]{2}{*}{ Species } & \multicolumn{3}{|c|}{ Apartments in } & \multicolumn{2}{|c|}{ One-family houses } & \multirow{2}{*}{$\begin{array}{c}\text { Public } \\
\text { utility } \\
\text { buildings }\end{array}$} & \multirow[b]{2}{*}{$\begin{array}{l}\text { BLS } \\
\text { group }\end{array}$} \\
\hline & $\begin{array}{c}\text { new } \\
\text { buildings }\end{array}$ & $\begin{array}{c}\text { over } 20 \\
\text { years old } \\
\text { buildings }\end{array}$ & $\begin{array}{l}\text { tenement } \\
\text { houses } \\
\text { over } 50 \\
\text { years old }\end{array}$ & $\begin{array}{c}\text { over } 20 \\
\text { years old }\end{array}$ & $\begin{array}{c}\text { over } 50 \\
\text { years old }\end{array}$ & & \\
\hline $\begin{array}{l}\text { Mucor } \\
\text { hiemalis } \\
\text { Wehmer }\end{array}$ & & ++ & & & & + & 1 \\
\hline $\begin{array}{l}\text { Penicillium } \\
\text { expansum } \\
\text { Link }\end{array}$ & & ++ & & & & + & 1 \\
\hline $\begin{array}{l}\text { Penicillium } \\
\text { meleagrinum } \\
\text { Biourge }\end{array}$ & + & + & & & & + & 1 \\
\hline $\begin{array}{l}\text { Penicillium } \\
\text { verrucosum } \\
\text { Dierckx }\end{array}$ & & & & & & + & 1 \\
\hline $\begin{array}{l}\text { Thamnidium } \\
\text { elegans Link }\end{array}$ & & & & & & + & 1 \\
\hline $\begin{array}{l}\text { total number } \\
\text { of species in } \\
\text { the buildings }\end{array}$ & 4 & 6 & 2 & 2 & 2 & 16 & \\
\hline
\end{tabular}

\section{Discussion}

In our study the representatives of Alternaria alternata and fungi from genera Aspergillus and Penicillium were the most common taxa. They were isolated and identified in 55\% of the buildings. Although Zyska (1999, 2001) mentions that Cladosporium s.l. spores are among the most common in the air, their number in our study was low. However, this research is in its initial phase and the results may be different in the further stages. Only two samplings made in the period of intense pollen occurrence showed significant presence of Cladosporium s.l. spores. In contrast, mould fungi belonging to Aspergillus genus have a very long period of sporulation, which is a likely cause of their intermingled presence with other taxa. Penicillium and Aspergillus representatives are among the most common and most cosmopolitan indoor species (Twarużek 2006), hence they were also widespread in buildings analysed in this study. Alternaria alternata was most commonly isolated in places that had damp plasters with humidity of $1-2 \%$, or more, or walls prone to frost. This fungus occurs also in all buildings which experienced flooding or had problems with insulation (Piontek 1999, Twarużek 2006, Ważny 2001). About $33 \%$ of taken samples contained conidiophores and conidia of Aspergillus niger. However, that fungus occurred only in over 50-year-old, neglected and 
unoccupied buildings. Penicillium fungi were mainly present (in 14\% of analyzed buildings) on wallpapers or wooden elements of construction or decorative elements as well as on the particle board furniture located in flooded rooms. Thamnidium elegans representatives, that are usually isolated from gardens, were isolated only from one-family houses (with gardens) or public utility buildings situated in parks. The spores get inside the apartments from the outside, thus the richer microflora occurrs outdoors, the more species are found in dwelling houses (Zyska 2001). Alternaria, Aspergillus and Penicillium fungi were detected mostly in apartments located in cities far from green areas. Acremonium spp. were identified in two apartments. Fusarium fungi occurred less commonly in public utility buildings. Pląskowska et al. (2012) mention that up to $35 \%$ of

\section{Conclusions}

The preliminary results allow presenting a list of 16 species of fungi occurring in residential and public buildings in the Warsaw area. The most frequently identified genera of fungi were Alternaria, Aspergillus and Penicillium. Some of the species

\section{References}

Gams, W. 1971. Cephalosporium-artige Schimmelpilze. Gustav Fischer Verlag, Stuttgart: 46-61.

Gerlach, W. \& Nirenberg, H. 1982. The genus Fusarium - a pictorial atlas. Biologische Bundesanstalt für Land- und Forstwirtschaft, Berlin.

Navi, S.S., Bandyopadhyay, R., Hal, A.J. \& Bramel-Cox, P.J. 1999. A pictorial guide for the identification of mold fungi on Sorghum grain. Information Bulletin no. 59. International Crops Research Institute for the Semi-Arid Tropics, Patancheru, India: 18-19.

Piontek, M. 1999. Atlas - Grzyby pleśniowe. Wydawnictwo Zielonogórskie, Zielona Góra.

Piotrowska, M. 2012. Czynniki sprzyjające rozwojowi grzybów pleśniowych w pomieszczeniach mieszkalnych. In: Karyś J. identified species in public utility buildings belong to Penicillium genus and up to $28 \%$ to genus Aspergillus. Alternaria fungi are most often isolated from the air in air-conditioned rooms, followed by the representatives of genera: Fusarium and Acremonium. On the other hand, the representatives of genus Cladosporium are rather typical for not air-conditioned places (Pląskowska et al. 2012).

The most allergenic species among the identified fungi was Aspergillus fumigatus classified to BSL-3 group, which means that even healthy people may potentially suffer from serious fungal infections (Grajewski et al. 2006). Other allergenic fungi are Aspergillus versicolor, $A$. ustus, $A$. niger and Alternaria alternata, which may trigger asthma.

belonging to these genera are classified as dangerous to the health of people exposed to contact with them. They include Aspergillus fumigatus and allergenic effect fungi - A. ustus or Alternaria alternata.

\& Krajewski K.J. (eds), Ochrona budynków przed wilgocią i korozją biologiczną. Wydawnictwo Polskiego Stowarzyszenia Mykogów Budownictwa, Wrocławpp, pp. 5964.

Pląskowska, E., Korol, M. \& Ogórek, R. 2012. Grzyby występujące w pomieszczeniach klimatyzowanych, cz. II. Mikologia Lekarska, 19(1): 27-36.

Raper, K.B., Thom, Ch. \& Fennel, D.I. 1949. Manual of the Penicillia. The Williams and Wilkins Company, Baltimore.

Thom, Ch. \& Raper, K.B. 1945. A manual of the Aspergilli. The Williams and Wilkins Company, Baltimore.

Twarużek, M. 2006. Grzyby pleśniowe i ich rola w środowisku. In: Grajewski J. (ed.), Mikotoksyny i grzyby pleśniowe - zagrożenie 
dla człowieka i zwierząt. Wydawnictwo Uniwersytetu Kazimierza Wielkiego, Bydgoszcz, pp. 18-25.

Watanabe, T. 2002. Pictorial atlas of soil and seed fungi morphologies of cultured fungi and key to species. CRC Press, Boca Raton, London, New York, Washington.

Ważny, J. 2001. Mikroorganizmy rozwijające się w budynkach. In: Ważny J., Karyś J. (eds), Ochrona budynków przed korozją biologiczną. Wyd. Arkady, Warszawa, pp. 52-90.
Wiejak, A. 2011. Ocena stopnia skażenia powierzchni zarodnikami grzybów pleśniowych jako istotny czynnik ekspertyzy mikologicznej. Prace Instytutu Techniki Budowlanej, 3(159): 3-12.

Zyska, B. 1999. Zagrożenia biologiczne w budynkach. Wyd. Arkady, Warszawa.

Zyska, B. 2001. Grzyby powietrza wewnętrznego w krajach europejskich. Mikologia Lekarska, 8(3-4): 127-140.

Zycha, H. \& Siepmann, R. 1969. Mucorales. J. Cramer Verl., Lehre.

\section{Streszczenie}

W pracy zawarto wstępne opracowanie badań mykologicznych w budynkach mieszkalnych i gmachach użyteczności publicznej w Warszawie i okolicy. Badania dotyczą jakościowego rozpoznania fungi $w$ obiektach $\mathrm{z}$ sześciu kategorii, które wydzielono w zależności od wieku budynków oraz ich przeznaczenia: mieszkania w tzw. „nowym budownictwie” oraz w obiektach około dwudziestoletnich i starszych, a także w dwudziestoletnich domach jednorodzinnych. W zakres analiz weszły również próby pochodzące $\mathrm{z}$ dwóch zabytkowych kamienic umieszczonych $\mathrm{w}$ rejestrze zabytków Narodowego Instytutu Dziedzictwa. Dokonano również próby zaklasyfikowania stwierdzonych gatunków grzybów pleśniowych do grupy BSL (Biological Safety Level), w celu wskazania ich potencjalnego oddziaływania alergogennego na użytkowników budynków.

W ponad połowie obiektów najczęściej izolowano Alternaria alternata (55\% przypadków) oraz grzyby z rodzajów Aspergillus i Penicillium, w tym Aspergillus niger, który zidentyfikowano w 33\% badanych obiektów: w budynkach zaniedbanych, w tym niezamieszkałych od przynajmniej roku. 